\title{
Synthesis of 5-Hydroxy-L-tryptophan Utilizing N-Acetyl-L-glutamic $\gamma$-Semialdehyde, an Intermediate in the Metabolism of L-Glutamic Acid to L-Ornithine
}

\author{
Shinobu IrIUCHIJIMA and Gen-ichi TsuchiHashi \\ Sagami Chemical Research Center, Nishi-Ohnuma, \\ Sagamihara, Kanagawa 229, Japan
}

Received November 15, 1977

\begin{abstract}
$\mathrm{N}$-Acetyl-L-glutamic $\gamma$-semialdehyde was enzymatically prepared in $51 \%$ yield from $\mathrm{N}^{\alpha}$-acetyl-L-ornithine. By the reaction with 4-benzyloxy(or methoxy)-phenylhydrazine this aldehyde was converted into $\mathrm{N}$-acetyl-5-benzyloxy(or methoxy)-L-tryptophan which is known to be transformed into 5-hydroxy-L-tryptophan, a biogenetic precursor of serotonin. By this work an amino acid of L-glutamic acid family was first chemically derived to that of L-tryptophan series.
\end{abstract}

5-Hydroxy-L-tryptophan (8) is an extremely important intermediate in the biogenetic synthesis of the intracerebral amine type hormones such as 5-hydroxytryptamine(serotonin), 5methoxytryptamine and $\mathrm{N}$-acetyl-5-methoxytryptamine(melatonin) from L-tryptophan in a living body. Further, it is useful as an antidepressant and has hormonal actions against Down's syndrome(Mongolism) and the like diseases. ${ }^{1,2)}$ The compound $\mathbf{8}$ was prepared by the optical resolution of $\mathrm{N}$-acyl-5-benzyloxyDL-tryptophan ${ }^{3,4)}$ or by the oxidation of 2,3dihydro-L-tryptophan. ${ }^{5}$ In the present paper we report a new synthesis of 5-hydroxy-Ltryptophan (8) from enzymatically prepared $\mathrm{N}$-acetyl-L-glutamic $\gamma$-semialdehyde (3). ${ }^{\text {b) }}$

In some bacteria ${ }^{\left.7 \sim^{\prime}\right)}$ and yeast ${ }^{101} \mathrm{~N}$-acetyl-Lglutamic $\gamma$-semialdehyde (3) is present as an intermediate in the metabolism of L-glutamic acid to L-ornithine while L-glutamic $\gamma$-semialdehyde is a biogenetic precursor of L-proline. We were interested in the $\mathrm{N}$-protected $\mathrm{L}$ glutamic $\gamma$-semialdehyde and intended to synthesize 5-hydroxy-L-tryptophan (8) from it because a variety of synthetic $\mathrm{N}$-protected glutamic $\gamma$-semialdehyde derivatives are known to be converted into optically inactive 5-hydroxytryptophan derivatives by the Fischer indole synthesis. ${ }^{1,11)}$

The aldehyde 3 was prepared in $51 \%$ yield from $\mathrm{N}^{\alpha}$-acetyl-L-ornithine (1) and $\alpha$-ketoglutaric acid (2) with the cell homogenate of Corynebacterium glutamicum (syn. Micrococcus glutamicus $)^{8}$ containing acetylornithine aminotransferase (EC 2.6.1.11). ${ }^{12)}$ Fisher cyclization reaction of 3 and 4-benzyloxyphenylhydrazine (4) in aqueous acetic acid gave $\mathrm{N}$-acetyl-5benzyloxy-L-tryptophan (6) in $88 \%$ yield after chromatography. Recrystallization afforded 6 of mp $198 \sim 199.5^{\circ} \mathrm{C}$ and $[\alpha]_{D}+6.3^{\circ}$ (reported values $^{4}$ are $m p 196.5 \sim 198^{\circ} \mathrm{C}$ and $[\alpha]_{D}+6.3^{\circ}$ ). The product 6 is known to be converted into $\mathbf{8}$ by the catalytic hydrogenation followed by the treatment with acid."

A similar reaction of 3 and 4-methoxyphenylhydrazine (5) furnished $\mathrm{N}$-acetyl-5-methoxy-L-tryptophan (7) in $65 \%$ yield. Recrystallization gave 7 of $\mathrm{mp} 173 \sim 175^{\circ} \mathrm{C}$ and $[\alpha]_{D}+$ $14.3^{\circ}$. The authentic sample 7 which was prepared by the acetylation of fermentatively produced 5-methoxy-L-tryptophan ${ }^{2)}$ showed mp $173 \sim 174^{\circ} \mathrm{C}$ and $[\alpha]_{\mathrm{D}}+14.7^{\circ}$.

Meanwhile, a similar reaction of 3 with phenylhydrazine (9) produced $\mathrm{N}$-acetyl-L-tryptophan (10) in $31 \%$ yield.

To the best of our knowledge, an amino acid of the L-glutamic acid family was first chemically derived to that of the L-tryptophan series by this work. Moreover, this work suggests a possible synthesis of useful compounds by the 

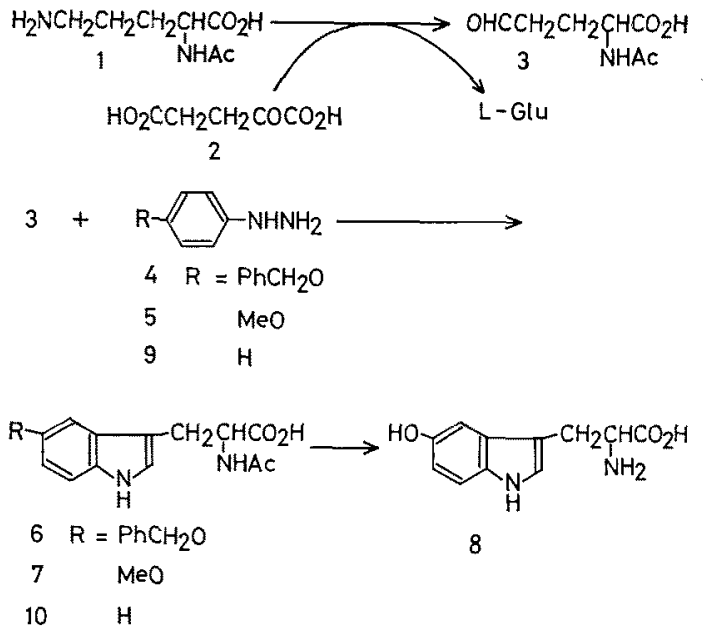

Fig. 1. Enzymatic Synthesis of $\mathrm{N}^{\alpha}$-Acetyl-L-glutamic $r$-Semialdehyde (3) and Its Conversion into 5Hydroxy-L-tryptophan (8).

combination of chemical and biochemical methods, utilizing intermediates in the biosynthetic pathways. It is well known that Lglutamic acid and L-ornithine are fermentatively produced. Therefore, it is interesting if the intermediate 3 between them is produced similarly. In fact 3 was isolated in $10 \mathrm{mg}$ per liter from a culture filtrate of Escherichia coli strain $160-37 .{ }^{7}$

\section{EXPERIMENTAL}

Melting points were taken on a Yanagimoto melting point apparatus and are uncorrected. IR spectra were measured on a Hitachi EPI-G3 spectrometer. The cell homogenate of $C$. glutamicum was prepared by Dr. Kazumi Araki using its arginine-requiring mutant according to the published method ${ }^{{ }^{3}{ }^{2}} \mathrm{~N}^{\alpha}{ }_{-}$Acetyl-iornithine was prepared in a conventional way from $\mathrm{N}^{\delta}$-benzyloxycarbonyl-L-ornithine (purchased from Kokusan Chemical Works) by the acetylation with acetic anhydride in the presence of aqueous sodium hydroxide followed by the catalytic hydrogenation.

Enzymatic preparation of $N$-acetyl-L-glutamic $\gamma$-semialdehyde (3)

A solution of $\alpha$-ketoglutric acid $(1.17 \mathrm{~g}, 8 \mathrm{mmol})$ and $\mathrm{N}^{\alpha}$-acetyl-L-ornithine $(1.39 \mathrm{~g}, 8 \mathrm{mmol})$ in water $(80 \mathrm{ml})$ was adjusted to $\mathrm{pH} 7.8$ with $1 \mathrm{~N} \mathrm{KOH} \mathrm{(ca.}$ $16.5 \mathrm{ml}$ ). To this solution were added $0.2 \mathrm{M} \mathrm{K}_{2} \mathrm{HPO}_{4}$ $(40 \mathrm{ml})$ of $\mathrm{pH} 7.8$, pyridoxal-5'-phosphate $\cdot \mathrm{H}_{2} \mathrm{O}(2 \mathrm{mg})$ and the cell homogenate $(15 \mathrm{mI})$ of $C$. glutamicum. The mixture was stirred at $36^{\circ} \mathrm{C}$ for $15 \mathrm{hr}$. It was cooled with ice water, brought to $\mathrm{pH} 3$ with $6 \mathrm{~N} \mathrm{H}_{2} \mathrm{SO}_{4}$ and extracted with butanol eight times. The extract was dried $\left(\mathrm{Na}_{2} \mathrm{SO}_{4}\right)$ and concentrated to an oily residue. The residue was dissolved in water $(5 \mathrm{ml})$ and slowly passed through $5 \mathrm{~g}$ of Amberlite $\mathrm{IR}-45$ ( $\mathrm{HCl}$ form). The resin was washed with water $(100 \mathrm{ml})$. The combined filtrates were concentrated at $50^{\circ} \mathrm{C}$ with a water aspirator to give an oil $(1.095 \mathrm{~g})$. This oil which is free from $\alpha$-ketoglutaric acid by NMR $\left(\mathrm{D}_{2} \mathrm{O}\right)$ still contains water and becomes glassy when dried under vacuum overnight.

A portion ( $84 \mathrm{mg}$ ) of this oil was treated with 2,4dinitrophenylhydrazine-sulfuric acid to produce $111 \mathrm{mg}$ (54 $\mathrm{mg}$ as 3) of the correrponding hydrazone. From this result, the yield of 3 was estimated to be $51 \%$. Recrystallization of the hydrazone from methanol gave mp $205 \sim 207^{\circ} \mathrm{C}$ (reported value ${ }^{7,8}$ ) is $\mathrm{mp} 208^{\circ} \mathrm{C}$ ).

Synthesis of N-acetyl-S-benzyloxy-L-tryptophan (6)

A stirred suspension of $91 \mathrm{mg}(0.34 \mathrm{mmol}$ as 3$)$ of the oil obtained above and 4-benzyloxyphenylhydrazine $\left.\cdot \mathrm{HCl}^{13}\right)(79 \mathrm{mg}, 0.315 \mathrm{mmol})$ in a mixture of water $(3 \mathrm{ml})$ and acetic acid $(4 \mathrm{ml})$ was heated gradually from room temperature to $80^{\circ} \mathrm{C}$ over $1 \mathrm{hr}$. At $80^{\circ} \mathrm{C}$ the reaction was stopped and the mixture was concentrated giving a residue. Water was added to the residue, and the mixture was extracted with ethyl acetate. The extract was dried, concentrated and dissolved in ethyl acetate-dichloromethane $(4: 6)$. The solution was applied to a silica gel (Wakogel C-200) column which was prepared with dichloromethane. Elution with ethyl acetate-dichloromethane (4:6) afforded $6(98 \mathrm{mg}$, $88 \%)$ of $[\alpha]_{D}^{26}+6.0^{\circ}(c=0.98, \mathrm{MeOH})$ which crystallized on standing. Recrystallization from ethyl acetatecyclohexane gave $85 \mathrm{mg} ; \mathrm{mp} 198 \sim 199.5^{\circ} \mathrm{C}$ and $[\alpha]_{\mathrm{D}}^{26}$ $+6.3^{\circ}(c=0.80, \mathrm{MeOH})$.

\section{Synthesis of $N$-acetyl-5-methoxy-L-tryptophan (7)}

A stirred suspension of $148 \mathrm{mg}(0.55 \mathrm{mmol}$ as 3$)$ of the above oil and $90 \mathrm{mg}(0.51 \mathrm{mmol})$ of 4-methoxyphenylhydrazine $\mathrm{HCl}$ (purchased from Aldrich, recrystallized from methanol) in a mixture of water $(3 \mathrm{ml})$ and acetic acid $(2 \mathrm{ml})$ was heated from room temperature to $80^{\circ} \mathrm{C}$ over $40 \mathrm{~min}$ and then heated at $80^{\circ} \mathrm{C}$ for $20 \mathrm{~min}$. The mixture was worked up and chromatographed in the same manner as the case of 6 to produce $121 \mathrm{mg}(65 \%)$ of $7,[\alpha]_{\mathrm{D}}^{23}+11.8^{\circ}(c=1, \mathrm{MeOH})$, which crystallized on standing. Two times recrystallization from ethyl acetate-cyclohexane gave 7 of $\mathrm{mp} 173 \sim$ $175^{\circ} \mathrm{C}$ and $[\alpha]_{\mathrm{D}}^{23}+14.3^{\circ}(c=0.725, \mathrm{MeOH}) . \quad \operatorname{IR} \nu_{\max }^{\mathrm{KBr}}$ $\mathrm{cm}^{-1}: 1215,1240,1535,1625,1730,2200 \sim 3100$, $3200 \sim 3450$. Found: C, 60.87; H, 5.93. Calcd. for $\mathrm{C}_{14} \mathrm{H}_{18} \mathrm{~N}_{2} \mathrm{O}_{4}: \mathrm{C}, 60.84 ; \mathrm{H}, 5.84 \%$.

\section{Preparation of 7 from fermentatively produced 5- methoxy-L-tryptophan}

To a stirred solution of 5-methoxy-L-tryptophan ${ }^{2}$ ) 
(95 $\mathrm{mg}, 0.406 \mathrm{mmol})$ in $0.1 \mathrm{~N} \mathrm{NaOH}(2.5 \mathrm{ml})$ was added acetic anhydride $(0.02 \mathrm{ml}, 0.21 \mathrm{mmol})$, and the mixture was stirred for $20 \mathrm{~min}$. To the mixture were added $0.5 \mathrm{~N} \mathrm{NaOH}(0.5 \mathrm{ml})$ and acetic anhydride $(0.06 \mathrm{ml}$, $0.63 \mathrm{mmol}$ ), and the mixture was stirred for $30 \mathrm{~min}$. The mixture was brought to $\mathrm{pH} 8 \sim 9$ with $1 \mathrm{~N} \mathrm{NaHCO}_{3}$ $(2 \mathrm{ml})$, and it was washed with ethyl acetate. The aqueous layer was acidified with $2 \mathrm{~N} \mathrm{HCl}$ and extracted with ethyl acetate. The extract was dried, concentrated and crystallized from ethyl acetate-cyclohexane. Recrystallization from the same solvent system furnished $83 \mathrm{mg}(74 \%)$ of $7 ; \mathrm{mp} 173 \sim 174^{\circ} \mathrm{C}$ and $[\alpha]_{D}^{23}$ $+14.7^{\circ}(c=0.79, \mathrm{MeOH})$.

\section{Synthesis of N-acetyl-L-tryptophan (10)}

A stirred suspension of $81 \mathrm{mg}(0.33 \mathrm{mmol}$ as 3$)$ of the oil obtained above and phenylhydrazine $\cdot \mathrm{HCl}$ (68 $\mathrm{mg}, 0.47 \mathrm{mmol})$ in acetic acid $(4 \mathrm{ml})$ was heated from room temperature to $80^{\circ} \mathrm{C}$ over 40 min and then heated at $80^{\circ} \mathrm{C}$ for $1 \mathrm{hr}$. The mixture was worked up and chromatographed as in the case of 6 to produce $25 \mathrm{mg}(31 \%)$ of 10 which partially crystallized on standing. The compound showed $[\alpha]_{\mathrm{D}}^{36}+21.6^{\circ}(c=0.5$, $\mathrm{MeOH}$ ) while the authentic sample (purchased from Tokyo Kasei Kogyo Co., Ltd.) had $[\alpha]_{D}^{26}+22.6^{\circ}(c=1$, $\mathrm{MeOH})$.

Acknowledgement. The authors express their sincere gratitude to Dr. Kazumi Araki, Tokyo Research Laboratory, Kyowa Hakko Kogyo Co., Ltd., for discussions and the preparation of the cell homogenate of $C$. glutamicum and Dr. Torao Ishida, Asahi Kasei Kogyo Co., Ltd., for the gift of 5-methoxy-L-tryptophan.

\section{REFERENCES}

1) N. N. Suvorov, L. M. Morozovskaya and G. M. Sorokina, J. Gen. Chem. U.S.S.R., 31, 864 (1961).

2) N. Kitajima, S. Watanabe and I. Takeda, U.S. Patent, 3915795 (1975).

3) A. J. Morris and M. D. Armstrong, J. Org. Chem., 22, 306 (1957); H. Rinderknecht, Helv. Chim. Acta, 47, 2403 (1964).

4) T. Kurano, H. Saito and T. Shioya, Japan Kokai, 7391063 [C.A., 80, 95724c (1974)].

5) Y. Mori and M. Sato, Ger. Offen, 2152088 (1972) [C. A., 77, 48786c (1972)].

6) S. Iriuchijima and G. Tsuchihashi, Abstracts of Papers, Annual Meeting of Agricultural Chemical Society of Japan, Yokohama, April, 1977, p. 162.

7) H. J. Vogel, Proc. Natl. Acad. Sci. U.S.A., 39, 578 (1953).

8) S. Udaka and S. Kinoshita, J. Gen. Appl. Microbiol. (Tokyo), 4, 272 (1958).

9) T. Kuo and B. A. D. Stocker, J. Bact., 98, 593 (1969); E. Yamamoto, Osaka Shiritsu Daigaku Igaku Zasshi, 18, 373 (1969) [C. A., 72, 63852m (1970)].

10) R.H. De Decken, Biochem. Biophys. Res. Commun., 8, 462 (1962).

11) K. Ogura and G. Tsuchihashi, J. Am. Chem. Soc., 96, 1960 (1974): G. Tsuchihashi and K. Ogura, Japan Kokai, 74 109373 4 [C. A., 83, 28560v (1975)].

12) A. M. Albrecht and H. J. Vogel, J. Biol. Chem., 239, 1872 (1964).

13) C. Mentzer, C. Beaudet and M. M. Bory, Bull. Soc. Chim. Fr., 1953, 421. 